\title{
Towards a History of Pneumatics: Writing Under Pressure, from Verne to Verne
}

\section{Edward Allen (University of Cambridge)}

On 17 April 1897, The New York Times printed a short letter of complaint. Readers had grown used by now to the rumble and grumble of commuters, but this correspondent - a visitor to New York City - had arrived at his own conclusion. 'Now, I am a progressive citizen,' he remarks (ominously) by way of a preamble, 'always interested in new things, especially great improvements and saving of time, \&c.,'

but the thought has just occurred, is there not a limit to the hurry and speed and crush of things that are forced into daily life.

The surface transit now of people, mail, and merchandise is infinitely ahead of the last time I was here, ten years ago, and really, in all truth, is it not good enough for another decade? Is not the cable postal car fast enough? ${ }^{1}$

Things on the 'surface' had certainly improved in the course of a decade. The introduction of a twenty-four hour service on the Sixth Avenue Elevated in 1882 had given rise in the 1890s to a railway network of superb scope, buttressed at its outer reaches by connections to the docks, roads, and a series of cable-car termini. Such a development seemed 'good enough' to most regular itinerants, so much so that the idea in 1897 of excavating NYC further in the name of 'hurry and speed' smacked of superfluity. The cause for concern was a length of mostly buried tubing - a pneumatic system - whose operational pressure would range from three to eight pounds per inch, and which promised under those controlled conditions to carry goods to and from the Lower East Side, thereby connecting the Stock Exchange, the main Post Office, and Grand Central Station. The irony, though it appears to have bypassed the odd grumpy visitor, was irresistible: in seeking to ease the density of surface cargo, the city authorities had simply decided to send the problem, and the pressure, underground.

My thanks to Michael Minden for commenting on an early draft of this essay; also to Renaud Morieux, who valiantly helped to hunt down an idiom, and to Arthur B. Evans, for an exchange about Robida's illustrations; and finally to the staff of my local supermarket, who allowed me to look at their pneumatic tube.

1 ‘Too Much of a Hurry’, The New York Times (17 April 1897), 6. 
Notwithstanding efforts such as this one to speak truth to (industrial) power, the pioneers of network theory have not often paused to gauge the material implications of pneumatic technology, or the public opinion it appears at times to have enflamed. In keeping with the age-old adage - out of sight, out of mind - the subterranean tubing makes no appearance in Stephen Kern's otherwise groundbreaking study of The Culture of Time and Space (1983); and the same is true of Friedrich Kittler's varied excavations, despite his glancing sensitivity in 'The City Is a Medium' (1996) to the rush of 'subway' traffic, and to the sorts of ephemeral information that cluster at the 'fringes, peripheries, and tangents'. ${ }^{2}$ Among the few to register the air of possibility that characterized for some the 'fanciful' innovation of pneumatics, Richard R. John lingers for a moment in Network Nation (2010) on the figure of John W. Post, who once touted the idea of propelling 'mail balls' at high speed along the eastern seaboard. The notion of transporting parcels 'with great velocity' had made the front page of Scientific American in 1853, and Post's intention three years later was to harness the growing opinion that an 'air-tight' solution had finally been found to the challenges of 'commercial progress'. ${ }^{3}$ His pitch did little by all accounts to persuade investors, and for John too, as for those who pooh-poohed Post's enterprise in 1856, the idea of an 'atmospheric telegraph', replete with pump and plunger, merely seems a footnote to media history and not a meaningful intervention in the course of its contested administration. ${ }^{4}$

Yet you don't need to be a media archaeologist to notice the traces of a definite fascination, in the fabric of our buildings or in the structure of our fictions. In 1901 H. G. Wells predicted that mainland Britain ('south of the Highlands', mind) would have to adapt soon enough to the burden of 'thickening traffic', and that it would undoubtedly find ways to relieve the pressure in one sense by increasing it in others - first by stimulating 'competition' within the postal and transport sectors, and then by generating between those sectors alternative conduits of exchange, from

\footnotetext{
2 Friedrich Kittler, 'The City Is a Medium', transl. Matthew Griffin, New Literary History 27 (1996), 717-29 (719, 718).

${ }^{3}$ Anon., 'Atmospheric Tube Telegraph', Scientific American 8.34 (7 May 1853), 26566.

${ }^{4}$ Network Nation: Inventing American Telecommunications (Cambridge, MA: Belknap Press of Harvard University Press, 2010), p. 105.
} 
'novel roads' to 'parcels delivery tubes'. 5 The fulfillment of Wells's prophecy would seem to rest, we might think, on the construction of Britain's motorways some sixty years later, but the fantasy of delivering parcels at high speed garnered instant admiration. Notwithstanding the 'inconvenience' to motorists of digging up the capital's roads, laying down pneumatic pipeline seemed the right way to go during the heat wave of 1906 precisely because so many of those putative motorists had something to dispatch: 'It is calculated that from one-sixth to one-quarter of the wheeled traffic of London is occupied with the distribution of mails and parcels', Archibald Williams reported that summer, somewhat hot under the collar, 'and if the tubes relieved the streets to this extent, this fact alone would be a strong argument in their favour'. ${ }^{6}$ The service's alleged 'immunity from traffic interruption' was evidently something to promote right away, but lest his readers attribute such pushiness to an untrammeled need for speed, Williams was careful to underline the system's antiquated selling point. Though quite as 'expeditious' as the electric telegraph, and equal in one sense to the capacity of surface mail, pneumatic technology looked set to combine the best of both - since 'all messages', Williams claimed, 'are transmitted in the sender's own handwriting'.

In proposing to marry qualities that have so often appeared incompatible speed and legibility - the pneumatic postal service poses a curious problem for the history of telecommunications, and in doing so sets the scene for this essay. It is no surprise at all, given the recent turn to the digital, to see a resurgence of interest in telegraphy, whose optical and electric forms required early operators to think of themselves as public-spirited cryptographers - programmers avant la lettre switching between code in ways that seemed to dematerialize communication as such. To put it another way (and that was the point, of course), one effect of turning printed alphabet into binary code was to streamline the mode of transmission, and so to relegate, without abandoning entirely, the idea that correspondents might want something to show for their communication, a proof of some originating gesture and

\footnotetext{
${ }^{5}$ H. G. Wells, Anticipations of the Reaction of Mechanical and Scientific Progress Upon Human Life and Thought, $2^{\text {nd }}$ edition (London: Chapman \& Hall, 1902), pp. 61, 260, 12.

${ }^{6}$ The Romance of Modern Mechanism (London: Seeley and Co., 1906), pp. 310, 313.

${ }^{7}$ Ibid., p. 305. (My italics.)
} 
the semblance of thick presence. ${ }^{8}$ A good deal of work has been undertaken lately to show that telegraphy signaled a new lease of life for the human being, not least for those aspects of the body - south of the neocortex - that have since been thought to play a constitutive role in disclosing and effecting processes of embodied cognition. ${ }^{9}$ What I want to suggest here, in deference to this critical trend but also by way of restitution, is that pneumatic technology did as much as telegraphy to enrich theories of telepresence in the heyday of point-to-point communication, and that its value, then and now, consists in its clunky and often counterintuitive resistance to the received wisdom of digital progress. As we'll see, the felt experience of pneumatic traffic was to become much more than a fleeting occupation.

\section{Pneumatic Bodies}

It's a mild November day in 1865, and anyone who's anyone in the communications business has travelled to central London. Imagine the scene on the High Holborn road: horse-drawn cabs and coaches, knifeboard buses, peddlers, apprentices and couriers, a pickle of latter-day Philip Pirrips dashing between assignments. Then imagine a property on this road - No. 245 - whose interior tributaries oblige you to take the path of least resistance:

the visitor passes along a corridor through a doorway, and emerges upon a gallery of considerable size, from which he looks down on a brick floor,

\footnotetext{
${ }^{8}$ For more on 'the limits of written textuality' in this period, see Richard Menke, Telegraphic Realism: Victorian Fiction and Other Information Systems (Stanford: Stanford University Press, 2008). I'm drawn here to the sense of 'thick presence' as Tim Leberecht deploys it in The Business Romantic: Give Everything, Quantify Nothing, and Create Something Greater Than Yourself (New York: Harper Collins, 2015), pp. 192-97. Drawing on the work of Clifford Geertz, Leberecht's unlikely model for thick presence is the online retailer Zappos, whose in-house policy now requires employees to prolong conversation with customers on the phone. The company, according to Leberecht, 'places value on being thickly present with each individual and not thinly present across an abstract data set' (p. 195). ${ }^{9}$ See, for example, N. Katherine Hayles, How We Think: Digital Media and Contemporary Technogenesis (Chicago and London: University of Chicago Press, 2012), esp. chapter 5; and Paul Gilmore, Aesthetic Materialism: Electricity and American Romanticism (Stanford: Stanford University Press, 2009). Gilmore nods in passing to the atmospheric telegraph, but his account centres on the electric variety.
} 
supporting lines of rails, much as he might do from a railway platform down on to the line, but from a greater elevation. Underneath the corridor by which he has just entered he sees some mechanical appliances, suggestive partly of an engine-room and partly of a pointsman's gallery outside a railway station... ${ }^{10}$

The inner workings of No. 245 provide a privileged, muted insight into the ways of modern traffic. For this is the last and latest stop on the pneumatic network, a marvel of the city's expanding infrastructure, which 'will soon be drawing in and delivering mail-bags from and to the postal head-quarters in London'. Not that these tubes should only be relied upon to carry letters. In time, it's said, their 'ordinary freight' is bound to include 'railway parcels, certain descriptions of market produce, and ultimately, it may be, general merchandise'. Most of the assembled crowd at the terminus are happy to accept this hypothesis and merely want to see the system in action. Typically, however, there are also those who can't help but push the envelope. Having conducted a series of exhibition runs, the engineer in charge is set upon by a group of scientists, all of them moved by 'a strong desire to pass through the tube themselves', and thus to test the stated dimensions (' $4 \mathrm{ft}$. in height by $4 \mathrm{ft}$. 6 in. in width'). The line, they're told, was never intended for 'passenger traffic', but nothing about the grimy journey - much less the risks of 'atmospheric propulsion' - can weaken the resolve of 'the middle-aged Englishman'. The 'excursionists' bundle into the vacant carts (each 'shaped like a capital D turned over on its straight side and mounted upon wheels'), and away they go to Euston Square at $25 \mathrm{mph}$, 'taking care to keep their heads well below the edge of the carriages'. Never mind the things folk say about boys and their toys, here's 'the spirit of adventure' and no mistake.

When the Pneumatic Despatch Company opened its doors and tubes to industrial scientists in November 1865, no-one in that select party would have been surprised to learn the scope and quality of 'atmospheric pressure'. In 1810 George Medhurst, a clockmaker from Kent, had published (though failed to patent) A New Method of Conveying Letters and Goods with Great Certainty and Rapidity by Air; and by the 1840s, with a little help from an experiment at Wormholt Scrubs, Medhurst's faith in the 'elasticity of Air' had diffused sufficiently to inspire practical

\footnotetext{
${ }^{10}$ Anon., 'The Pneumatic Despatch', The Times (8 November 1865), 10. Further quotations in the text derive from this report.
} 
application, first on the Dalkey Line in County Dublin (1844), and then on railway routes from London to Croydon (1846) and Exeter (via Dawlish) to Newton Abbot (1847). ${ }^{11}$ Trains on the Devon line are reckoned to have surpassed $60 \mathrm{mph}$, but not even Isambard Kingdom Brunel could make pneumatics pay, and an alternative to locomotive transport would not materialise again as a serious proposition until the early 1860s, when projects in Battersea and Sydenham each displayed brief signs of momentum. ${ }^{12}$ The interest of the metropolitan line's first reported outing in November 1865 is of a different order. For the queer thing, looking back, about the dry run in Holborn is not that the gentlemen thought of themselves first or only as 'excursionists', but that they were happy to masquerade as cargo, some of them draped in tarpaulin, others packed between ballast and bags of shingle (Fig. 1). As Kate Thomas remarks in Postal Pleasures, by '[t]raveling with, or as, the mail, these men lose the markers of class and status, and gain a thrilling and sensory association with other men possessed of the same daring desires'. ${ }^{13}$ The prospect of venturing in this mood into the 'mouths' of the new catacombs may not have been wholly lost on the Times reporter, who was swift to register the 'curious sensation' of penetrating 'utter darkness', and of negotiating the 'intricate fibres of the London subsoil-way'. More revealing than his show of erotic intrepidity, perhaps, is the reporter's subsequent attempt to repress or gloss over the feeling that he may not have got off scot-free. Where Thomas is keen to extrapolate the 'transformative' effects of the journey to and fro, and to wonder what its long-lasting appeal might be for the serial pleasure seeker, the reporter-at-large does his best to walk away from the carriage with a modicum of self-possession, convinced that a 'double transit' merely takes you

\footnotetext{
${ }^{11}$ Medhurst, A New Method of Conveying Letters and Goods with Great Certainty and Rapidity by Air (London: D. N. Shury, 1810), p. 5. For a more detailed history of atmospheric railways, see Charles Hadfield, Atmospheric Railways: A Victorian Venture in Silent Speed (Newton Abbot: David \& Charles, 1967).

12 The pneumatic line that was unveiled at Crystal Palace in 1864 drew considerable attention, particularly from commentators in the United States, who could see the 'practical utility' of the new system: 'Another Pneumatic Railways in London', Scientific American 13.2 (8 July 1865), 18. A homegrown service would eventually break ground in the form of New York's Beach Pneumatic Transit in 1870, for which see http://www.nycsubway.org/wiki/Beach_Pneumatic_Transit (accessed 1 August 2016).

${ }^{13}$ Postal Pleasures: Sex, Scandal, and Victorian Letters (Oxford: Oxford University Press, 2011), p. 3.
} 
back to where you started, and not - in more immanent ways - into uncharted territory.

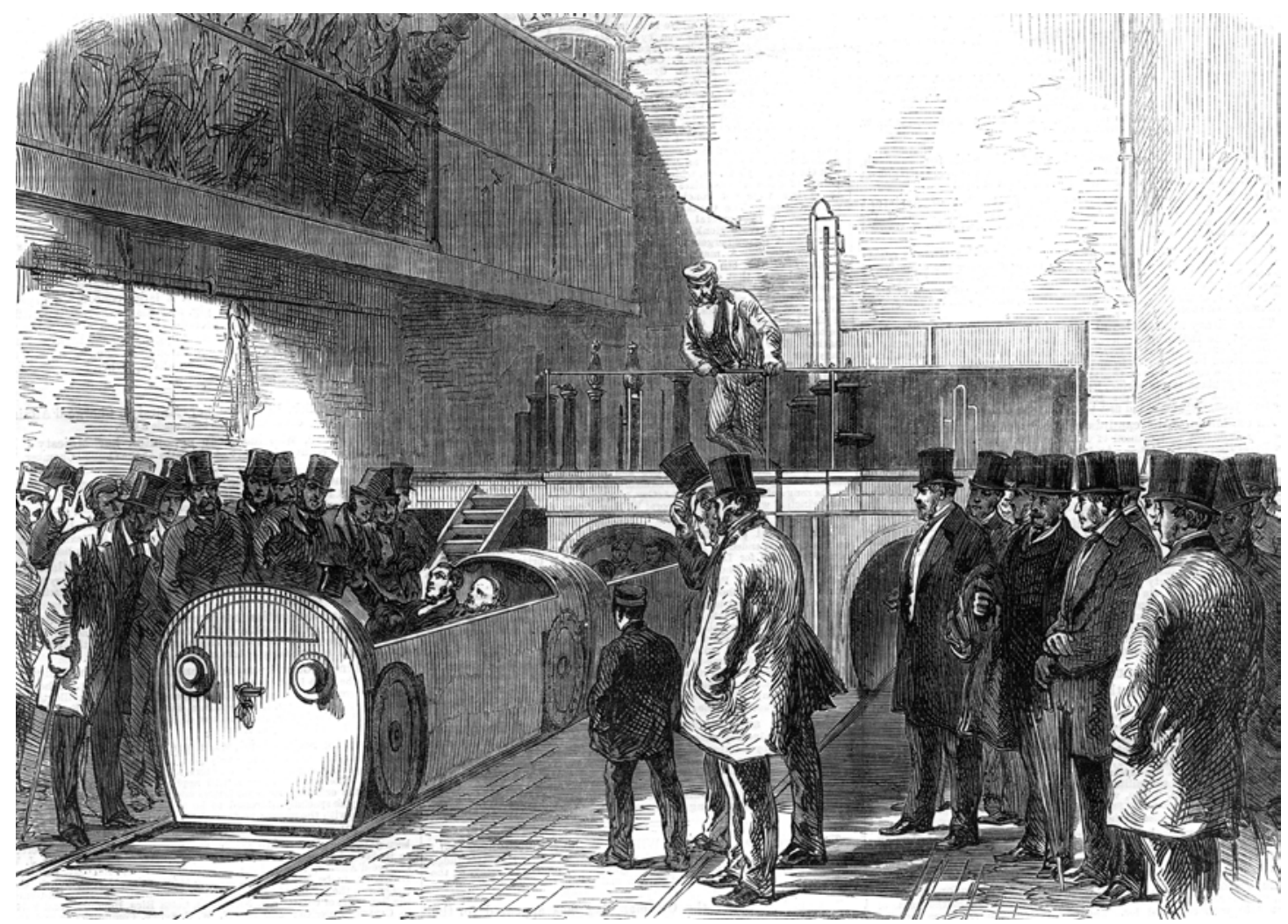

Figure 1. 'The Pneumatic Despatch Tube: The End of the Tube at Holborn on the Opening Day', Illustrated London News (18 November 1865), 493. (C) Illustrated London News / Mary Evans Picture Library

There were several reasons in 1865 for playing down the affective oddities and somatic quirks of pneumatic transportation in favour of promoting its utility. As the Times reporter knew only too well, London's 'glut of traffic' had begun to press on the finer seams of the city's infrastructure, prompting authorities to search for quiet, affordable solutions, and to dispense with schemes that had left the city looking outmoded, Victorian before its time. ${ }^{14}$ The Pneumatic Despatch Company, founded in 1859, witnessed growing support in its first decade of operation, thanks in large part to favourable reviews in the popular press, but Kate Thomas is quite right to surmise that the technology had already done something to condition the way people were feeling and thinking, if not in London then further afield. Unbeknown to

\footnotetext{
${ }^{14}$ See R. Dudley Baxter's recommendations in 'Railways Extension and its Results', Journal of the Statistical Society of London 29.4 (1866), 549-95.
} 
contemporary readers, because his manuscript would only come to light in 1989, Jules Verne had set his mind in 1863 to Paris au $X X^{e}$ siècle, a novel much congested with 'la multiplicité des affaires'. ${ }^{15}$ Verne’s uneven tale unfolds in 1960s Paris, a vision of the capital that '[a] crevé son enceinte', and which seems in that way to anticipate the fraught stomping ground of a fantasy like Jacques Tati's Playtime (1967). ${ }^{16}$ Verne's protagonist, Michel Dufrénoy, does indeed have something of Tati's white-collar clown about him: in the manner of the deliberate, unhurried and perennially inquisitive Monsieur Hulot, the poet Dufrénoy has his own style of locomotion, his own wandering grammar, 'n’étant point de ces écoliers quie se préciptent dans les vacances comme les peuples dans la liberté' (p. 41). ${ }^{17}$ And like Hulot, whose bouts of confusion stem invariably from mechanical misadventure, Dufrénoy is doomed to remain a student of the metropolis and the butt of modernity's jokes, one who pauses even now to notice an elevator rising 'par un movement insensible' (p. 50). ${ }^{18}$ To do so brings little comfort to Dufrénoy, who feels 'seul, étranger', and whose sensitivity to 'insensible' things is unmatched by those around him, a society long since inured to the technological sublime. ${ }^{19}$ Among those to host the hapless minstrel as he searches for a profession is Monsieur Stanislas Boutardin, who appears to be 'le produit naturel de ce siècle d'industrie', and a man who thus accounts for life 'par les engrenages ou les transmissions' (p. 51). ${ }^{20}$ It is not that Dufrénoy is invulnerable to the stimuli of city life, for he too registers the odd 'étincelle communicative' (p. 80), but rather that he alone can see what's become of le Gai Paris. When he finds himself traipsing into a morgue, 'machinalement' (p. 195), he knows the game is up, and so do we. ${ }^{21}$

Central to Verne’s dystopian vision of twentieth-century Paris is one network in particular, a train run 'à l'aide de l'air comprimé' (p. 45). ${ }^{22}$ The benefits of this system are palpable - 'pas de fumée, pas de vapeur, pas de rencontre' (p. 46) - and

\footnotetext{
${ }^{15}$ Paris au $X X^{e}$ siècle (Paris: Hachette, 1994), p. 48. Richard Howard renders this phrase 'the pressure of business'. All translations are taken from his edition, Paris in the Twentieth Century (New York: Ballantine, 1996).

16 'ha[s] burst its precincts', p. 18.

17 'not being one of those schoolboys who rush into vacation like a subject people into freedom', p. 17.

18 ‘imperceptibly’, p. 28.

19 'alone, alien', p. 16.

20 'the natural product of this age of industrial development', 'by gears and transmission', pp. 29-30.

21 'communicative spark', 'mechanically’, pp. 67, 206.

22 'by means of compressed air', p. 22.
} 
the government is swift to appease commuters by rolling out a network that is 'rapidité...facilité...bien-être' (p. 43). ${ }^{23}$ Verne’s fondness for the smart rhythm of a tricolon is striking, yet the effects of pneumatic traffic steal in less comfortable ways into the minds and ears of the city's residents, who must put up with the drivel - and yes, the hot-air - of the ruling bureaucratic class:

Ce discours furibond rappelait à s’y méprendre les sifflements, les frottements, les gémissements, les mille bruits désagréables qui s’échappent d'une machine à vapeur en activité; le debit pressé de l'orateur ressemblait à un volant lancé à toute vitesse; il eût été impossible d'enrayer cette eloquence à haute pression, et les phrases grinçantes s’engrenaient comme des roués dentées, les unes dans les autres. (pp. 35-36) ${ }^{24}$

In propounding 'la litanie des découvertes modernes', the incumbent Director of Applied Sciences becomes not only a figure of fun, but a victim of his own vocation. The impact of the applied sciences is everywhere conspicuous in his oratorical display, such that it becomes difficult to separate the man from his subject, or indeed to say whether he embodies the future or simply represents a calamitous throwback. His effusions recall those of a machine the city has all but left behind - the steam locomotive - yet these lines convey something too of the new regime, which now enjoys a more efficient mode of delivery, 'un volant lancé', and may well forgive a homily of this sort if it's executed 'à haute pression'. Though prone to dissipate in translation, the force of that compacted word, 'pression', can be heard and felt throughout the novel, in 'le debit pressé de l'orateur', whose tongue runs away with him, and in the very deportment of modern Parisians, 'leur allure pressée' (p. 48). ${ }^{25}$ For those who rely on the Catacomb Company for their transportation each day, 'pression' has become a way of life, it seems (p. 52); all except for Dufréynoy,

\footnotetext{
23 'no smoke, no steam, no collision', 'rapidity, facility, and comfort', pp. 23, 20.

24 'His furious oration was remarkably similar to the whistles, groans, jangles, squeals, the thousand unpleasant noises which escape an active steam engine; the speaker's rapid delivery suggested a projectile hurtling at top speed; it would have been impossible to stem this high-pressure eloquence, and the grating phrases locked into one another like cogwheels', p. 11.

25 'their hurried gait', p. 26.
} 
perhaps, who takes his time and sets the pace - 'il ne se press[e] pas' (p. 41) - or so he'd like to think... ${ }^{26}$

\section{The Quick and the Dead}

Save for 'un singulier movement de satisfaction ironique' (p. 191), Dufréynoy’s last days in Paris pass without remission, pestered and pressed as he is by 'le demon de l'electricité'. Verne's is a chronic and unforgiving technological determinism, unmotivated by the principles of consolation that might, in his agent's opinion, have made the tale credible and shapely, and have brought it into line with his previous fictional outing, Cinq Semaines en ballon (1863). ${ }^{27}$ It is also possible that the agent deemed Verne’s futuristic Paris a touch behind the times. Towards the end of chapter two, Verne's narrator lampoons the men of 1960, and attributes their 'fougue américaine' to 'le demon de la fortune' (p. 48). To later readers of Verne, such OldWorld snobbery must seem an aberration, not only because the author would find so much to admire about the American pace of life in the 1860s, but also because the 'fougue' he has in mind in Paris au $X X^{e}$ siècle had arisen much closer to home. ${ }^{28}$ News of the Dalkey Line in County Dublin had enticed a delegation of French engineers in 1844, and the following years had witnessed a wave of locomotive innovation in western Paris, including the work of Isaac Pereire, who proposed to extend a route to Saint-Germain by instituting a pneumatic line. As with earlier attempts to do so in Britain and Ireland, Pereire's bid to persuade all interested parties of the system's efficacy had mixed results, and if for a time the shareholders seemed enthusiastic, the newspapermen were never really onboard. ${ }^{29}$ Having lost the backing

\footnotetext{
26 'he proceed[s] quite unhurriedly', p. 17.

${ }^{27}$ Pierre-Jules Hetzel wrote in these disappointed terms to Vernes shortly after he'd submitted the manuscript: 'Il n'y a pas là une seule question d'avenir sérieux résolue, pas une critique qui ne ressemble à une charge déjà faite et refaite': Un éditeur et son siècle: Pierre-Jules Hetzel, 1814-1886 (Saint-Sébastien: ACL Édition, 1988), pp. 118-19. For more on the publication history of the novel, see Piero Gondolo della Riva's introduction to the French edition (pp. 11-24); Arthur B. Evans provides one of the first accounts in English of the novel in 'The "New" Jules Verne', Science Fiction Studies 22.65 (1995), 35-46.

${ }^{28}$ Evans surveys Verne’s transatlantic passions in 'Jules Verne’s America', Extrapolation 48.1 (2007), 35-43.

${ }^{29}$ See Hadfield, Atmospheric Railways, pp. 177-86.
} 
of the Journal des Chemins de Fer early in the 1850s, Pereire's line resurfaced once more, but for all the wrong reasons, in September 1858, when 'un bien cruel accident' left three passengers dead and more than thirty injured. ${ }^{30}$ Had Verne's novel appeared in 1863, Parisian readers might have considered his pneumatic fantasy ('pas de fumée, pas de vapeur, pas de rencontre') the stuff of wishful thinking.

As it is, the business of trafficking bodies remained a subject of intense debate in Second Empire Paris. The human cost of experiments such as Pereire's could not be borne, but nor would the expense of transporting the dead seem an easy thing to countenance under Napoléon III, whose closest Prefect, Georges-Eugène Haussmann, had grand plans for the capital's challenged and challenging infrastructure. One such plan, posited in 1864, was to send the city’s bodies out to a plot in Méry-sur-Oise, some twenty kilometres north of Paris, thereby putting an end to three of the most crowded cemeteries in operation. Few Parisians were spared the monumental effects of Haussmannisation, as Flora Willson has shown, and although this latest commission soon sputtered to a halt, it did something to instil an idea that the very ceremony of trafficking had begun to change. ${ }^{31}$ If a funeral cortege could be repackaged as a suburban delivery service, then who was to say what Haussmann would instigate next? Last rites at railway termini? Timetables for La Touissant? Was nothing sacred? Léon Vafflard, an authority in these matters, had gone to some trouble in the wake of Haussmann's initial proposal to denounce the creep of newfangled customs - particularly those practised in London - and to ridicule any policy that purported to turn a corpse into 'un colis' [a package]. ${ }^{32}$ Yet even Vafflard, who knew a business opportunity when he saw one, had changed his tune by 1867:

Ces trains pourront donc emmener, au fur et à mesure de leur arrivée, les corps ainsi que les parents ou amis qui voudront les accompagner jusqu’à destination, sans leur faire subir aucun retard fâcheux.

\footnotetext{
30 'L'accident du train atmosphérique en gare du Vésinet, le 6 septembre 1858', Journal de Versailles (9-12 Septembre 1858). See also Paul Smith, 'Les Chemins de Fer Atmosphériques. Deuxième Partie’, In Situ: Le Patrimoine Scientifique 10 (2009), 2-63.

${ }^{31}$ I am grateful to Flora Willson for sharing with me her unpublished chapter, 'Haussmannising Death'.

${ }^{32}$ Vafflard, cited in Michel Ragon, L'espace de la mort: Essai sur l'architecture, la décoration et l'urbanisme funéraires (Paris: Albin Michel, 1981), p. 282.
} 
These trains will thus transport - as and when they arrive - both the corpses and the relatives or friends who wish to accompany them to their destination, without making them endure any unpleasant delay. ${ }^{33}$

Vafflard's message is plain enough, but its ambiguities are delicious. For once you begin to think about trafficking the living and the deceased ensemble, it is not so easy (though no less necessary for that) to distinguish one 'corps' from the other, or to parse their shared rites of passage. Whose appearance is anticipated in that easy-going sub-clause - 'leur arrivée' - the trains, the bodies, the parents, or friends? And if the 'destination' pertains, as it must under the new orthodoxy, to corpses and survivors alike, you've got to wonder whose journey Vafflard is hoping to expedite when he closes down the possibility of a 'retard fâcheux'. Who, in the end, is the funeral director in such a rush to dispatch, the quick or the dead?

To the relief of most self-respecting Parisians, Haussmann's death train was never given the go-ahead. Following the Prefect's departure from office in 1870, the matter of urban transportation became someone else's problem, and with it went the ethical concerns that are part and parcel of mediating human traffic. The problem of conveying bodies, dead or alive, would outlive the succeeding administration, and Paris was to remain for many years a picture of ill-health, a byword for congestion and sordid intimacy. Among those to witness the 'gueuletons' [gluttonous orgies] of the Second Empire, the Quenu family in Zola's Le Ventre de Paris (1873) set up shop in Les Halles, the food market that had undergone renovation in the years of Haussmann. Lisa Quenu speaks of the capital's underbelly in fearful ecstasy, mindful that an estranged cousin, poor soul, 'est toujours par voies et par chemins, au milieu de trafics d'enfer' [is always coming and going, up to his neck in hellish traffic]. ${ }^{34}$ Novelists had long striven to articulate this frisson of urban chaos, 'un monde où la distance a disparu', as Victor Hugo puts it in Napoléon le Petit (1852), 'un monde toute circulation et tout amour' [a world where distance has disappeared...a world

\footnotetext{
${ }^{33}$ Léon Vafflard, Notice sur les champs de sépultures anciens et moderns de la ville de Paris (Paris: Charles de Mourges Frères, 1867), pp. 30-31. The translation provided here is Willson's.

${ }^{34}$ Le Ventre de Paris (Paris: Lettres Modernes, 1969), pp. 126, 110. The title of the novel has been variously rendered as The Fat and the Thin, and The Belly of Paris. The translation offered here is mine.
} 
that is all circulation and love]. ${ }^{35}$ But rather than plumping for circulation himself - a word widely used in urban planning since the 1850s, and favoured by the likes of Hugo - Zola settles for trafics in Le Ventre de Paris, a freighted and yet more slippery term, which bears the stamp of contraband and double-dealing. ${ }^{36}$ In probing the city's 'trafics d'enfer', Zola has something like a black market in mind.

Underworld trafficking was to remain a dubious fantasy, not least for the many students and satirists of Jules Verne. The spectre of body bags - figures made to look and sound like parcels - was too palpable to put to rest, and one novelist in the 1880s could see the idea catching on:

Hélène arriva juste pour le départ du train. Elle avait son carnet de timbrestubes qui servent à payer les voyages sur n’importe quelle ligne, comme les timbres-poste pour les lettres; elle n'eut donc qu’à monter en tube. [...] Quelle formidable puissance que celle qui projette ainsi quarante cylindres et huit cents voyageurs avec une vitesse de quatre cents lieues à l'heure et, ce qu'il faut noter, avec la plus complete sécurité pour les personnes entassées dans les cylindres! Quel progress réalisé depuis les capilotades de voyageurs du temps des chemins de fer!

Hélène arrived just in time for an immediate departure. She already had a book of tube stamps - which are used as payment for tube trips just like postage stamps for letters. Therefore, all she had to do was to get on board. [...] Hurled through the tube by the formidable power of electricity and air combined, the forty cylinders carried eight hundred passengers at a speed of four hundred leagues per hour, all this - it cannot be stressed enough - with the utmost safety for the people sitting in the train. What progress had been

\footnotetext{
${ }^{35}$ Napoléon le Petit (Paris: Laffont, 1987), p. 149.

${ }^{36}$ See, for instance, Actes et Paroles (1875-76), in which Hugo returns repeatedly to the unifying figure of 'la circulation'. 'En monnaie, comme en toute chose, circulation, c'est unité' [In currency, as in all things, traffic is unity]: Actes et Paroles II: Pendant L'Exil, 1852-1870 (Paris: Laffont, 1985), p. 484.
} 
accomplished since the days when railroad accidents would often smash passengers to smithereens! ${ }^{37}$

It is difficult to keep pace with this frenetic passage, though it begins methodically enough. The passenger, Hélène, knows where she’s going (Bordeaux), and it doesn't occur to her - as perhaps it doesn't occur to us by now - that carrying a 'carnet de timbres-tubes' might begin to feel like a category error. To assume that using the tube is a bit like mailing a letter is charming but mistaken, for it remains her responsibility, and not the courier's, to keep an eye on where she's posted. The chances of missing her stop are more than usually high, given the speed she’s travelling (1112 mph), and that is precisely what happens. As the facts and figures of the miraculous vehicle whizz past - its mechanics, its capacity, its commitment to health and safety - so does Hélène's destination. A malfunction causes her tube to collide with the one behind it, and so she finds herself buffeted all the way to Madrid, not in 'capilotades', but in pieces, nonetheless.

Hélène's is an object lesson in the performance of this special issue's rubric: traffic-sense. ${ }^{38}$ It deserts us all from time to time, but the attendant threat of discomposure seems a more critical one in the case of Hélène Colobry, who must get up to speed with the laws of physics if she's to grasp those of the modern city. Having uprooted to Paris, the countrified Hélène is reminded at every turn that she is behind the times (“"vous n'êtes pas de votre temps!”’), and while she's capable of thinking on her feet, pedestrian intuition is not always enough to see her through the senseshifting echelons of Le Vingtième Siècle. Penned in 1882, and set in the early 1950s, Robida's novel looks forward to a time that sounds uncomfortably like our own - a time of federal liquidation and 'gouvernement mécanique' (p. 269), a time where anything goes in the media sector, thanks to the 'telephonoscope' (p. 50), but one in which war correspondents are advised to wear 'gilet[s] paraballes' (p. 233) [bulletproof vests]. Though unflinching in its way, Le Vingtième Siècle is a complex, faux naïf response to the ruinous behaviour of Second Empire Paris, and Robida displays his political colours less conspicuously than his Naturalist counterparts or his utopian

\footnotetext{
${ }^{37}$ Albert Robida, Le Vingtième Siècle (Paris: Georges Decaux, 1882), p. 117. I follow Philippe Willems's translation: The Twentieth Century, ed. Arthur B. Evans (Middletown, CT: Wesleyan University Press, 2004), pp. 156-57.

${ }^{38}$ See Purdon, 'Modernism’s Traffic-Sense'.
} 
rivals, particularly those of a socialist persuasion, such as Edward Bellamy and William Morris. ${ }^{39}$ Rather than setting to work on the city’s slums, Robida rises above them, inspired by the thought that 'il reste le pays des nuages' (p. 40) [there is always cloudland], a place where earthly desires are wont to evaporate, and gridlock will seem a distant dream. In promoting the ways of 'la circulation aérienne' (p. 37) [aerial traffic], Robida not only elevates the lowly bildungsroman, but also generates for the novel a new and disquieting horizon of expectations, according to which hospitals appear out of the blue, holiday-homes seem to dangle, and the towers of Notre-Dame provide the platform for a giddy dining experience à trois (p. 78). If, as Steven Connor suggests, air has a history all of its own - a history, especially towards the end of the nineteenth century, of 'interference' and 'congestion' - then this might be its apotheosis. $^{40}$

As Hélène drifts from one failed occupation to the next - first a barrister, then a journalist, later a financier - we gather that the backdrop to her hopeless careering, the 'pays des nuages', operates much as terrestrial nation-states do, with the crucial exception that all signs of border control have dissolved. 'Ce mot barbare de frontière est bien démodé', we learn towards the end of the novel, since 'la navigation aérienne a depuis longtemps supprimé les anciennes barrières’ (p. 304) [The barbaric term border has been out of fashion for quite a time. Aerial navigation long ago put an end to those old artificial barriers]. The dissolution of 'anciennes barrières' was to become a peculiarly mobile philosophy in the following decade, particularly in the United States, where Frederick Jackson Turner would lead the way in theorizing national character as a product of the 'ever retreating frontier', all the while mourning the news that pioneers had exhausted western territory. ${ }^{41}$ The prophetic Robida could not have guessed the results of the 1890 Census that would do so much to shape Turner's thesis, and to colour the proceedings of the Chicago World's Fair in 1893. Yet Robida was never one to give up easily in the absence of hard data, and there is a moment in Le Vingtième Siècle that suggests he could see the way things were going:

‘il faut le reconnaître, le grand danger pour l’Europe, c’est l’Amérique: les

\footnotetext{
${ }^{39}$ See, for instance, Bellamy’s Looking Backward: 2000-1887 (1888), and Morris’s News from Nowhere (1890).

${ }^{40}$ The Matter of Air (London: Reaktion, 2010), p. 38.

41 'The Significance of the Frontier in American History' (1893), repr. with minor revisions in The Frontier in American History (New York: Holt, 1921), p. 38.
} 
adversaires de notre tunnel ont touché juste, notre vieille Europe est fortement menacée par la jeune et remuante Amérique. Les trois cents millions d’hommes du Nord-Amérique et les deux cents millions du Sud commencent à se trouver à l'étroit sur leur continent...'

'We might as well face it: the greatest threat facing Europe is America! Our tunnel's adversaries are right to say that our old continent is at risk from this young and growing New World. The three hundred million inhabitants of North America, as well as the two hundred million of the Southern continent are starting to feel cramped...' (p. 258)

The tunnel in question is the brainchild of Hélène’s uncle, Raphaël Ponto, a moneyed 'utopiste' (p. 271), who's assumed the task of lacing the globe with pneumatic tubes. The 'tunnel transatlantique' exceeds the ungrounded fancies of a pipedream, since plans are already afoot at the tube's midsection to build 'un village et des hotels sousmarins', replete with 'une belle promenade circulaire le long des arcades vitrées’ (p. 259) [a submarine village with hotels...a beautiful circular promenade along the arcades]. A late arcadian, Walter Benjamin, might have smiled to hear the stirrings of Baudelaire in this vision of far-flung Parisian life, 'more submarine than subterranean', yet he would also have flinched to survey Ponto's sanitized arcades, in which 'vitres de cristal' slot into place as though nothing's changed since the days of the Second Empire. ${ }^{42}$ Just as a 'predilection for perspectives, for long open vistas' had prompted Haussmann back in the 1850s to 'dictate art forms to technology' - and so, in Benjamin's view, to reduce 'city planning' to an exercise in 'kitsch' - Ponto presents his board of directors with an eye-catching and no less frivolous instance of mediation: a pneumatic tube that doubles as an aquarium. ${ }^{43}$

\footnotetext{
${ }^{42}$ Walter Benjamin, The Arcades Project, trans. Howard Eiland and Kevin McLaughlin (Cambridge, MA: Belknap Press of Harvard University Press, 1999), p. 10 .

43 The Arcades Project, p. 126. Benjamin's original fragment is characteristically laconic: 'Haussmanns Bevorzugung der Perspektiven stellt einen Versuch dar, der Technik (der urbanistischen) Kunstformen aufzuoktroyieren. Dieser führt immer zum Kitsch.' Das Passagen-Werk, Gesammelte Schriften, ed. Rolf Tiedemann, vol. 5 (Frankfurt: Suhrkamp, 1982), p. 186. Further quotations from Tiedemann's edition appear in square brackets in the text.
} 
The question arising in this scene, though nowhere voiced, has to do with the function of the tube's intended traffic. To put it that way might be to return belatedly to first principles - what is traffic? does it need a function? - yet this is precisely the sort of speculation Ponto allows to thicken as he presents the case for a different kind of line, prompting one to philosophize more deeply about the places a tunnel may take you, the distractions it might entail, the dreams it could permit. For if, as Ponto implies, his pneumatic infrastructure has become something more than a conduit - not so much a passing place as a place to pass the time - is it accurate still to think of its contents as traffic?

Trade and traffic are the two components of the street. Now, in the arcades the second of these has effectively died out: the traffic there is rudimentary. The arcade is a street of lascivious commerce only; it is wholly adapted to arousing desires. Because in this street the juices slow to a standstill, the commodity proliferates along the margins and enters into fantastic combinations, like the tissue in tumors. - The flâneur sabotages the traffic. Moreover, he is no buyer. He is merchandise. ${ }^{44}$

This is not quite the way Ponto puts it to his touchy board of directors; their confidence as an investment body hinges, after all, on the evidence of 'grey literature' - reports, surveys, white papers - and not on the fugitive designs of historical materialism. Yet Benjamin's snapshot of the arcades' lurid economy is illuminating, not least for the specific things it has to tell about traffic's semantic drift. That innocuous word, 'traffic', is required here to do the dirty work of Verkehr, which for Benjamin (as for any German speaker) carries a sense of transportation, yes, but also one of abstracted data flow, of social relations in the act of becoming a brand of commerce or exchange. The contours of Benjamin's term are reminiscent of the particular tonal frictions that characterize The German Ideology of Marx and Engels, and it's probable that the arcadian also shares with them a feeling for the word's libidinous undertones, which render Verkehr a vehicle not only for social relations, but for full-blown intercourse too. ${ }^{45}$ This is one of the senses Benjamin means to

\footnotetext{
${ }^{44}$ The Arcades Project, p. 42.

${ }^{45}$ See Die Deutsche Ideologie (1932), in Marx Engels Werke, vol. 3 (Berlin: Dietz Verlag, 1973), p. 21. For more on Marx’s evolving sense of the term, see Jay Geller,
} 
activate when he evokes the 'rudimentary' quality of life passing through the arcades, a stream of urban traffic that has lost its momentum, and fallen prey to a more primitive inner drive [die Begierden zu wecken]. The capital's complex of glass and iron has become the seediest of hothouses, thick with evidence of new life [die Säfte] and abundant with the kind of 'fantastic combinations' [phantastische Verbindungen] that should remind us that Benjamin, as always, has Baudelaire firmly in his sights. Just as his predecessor could see something 'fécond' about a candle-lit window - a medium for steamy self-reflection - Benjamin pauses in the arcades to think through such fecundity, and so perhaps to shake up the idea that the flâneur operates like 'un kaléidoscope doué de conscience'. ${ }^{46}$ In looking, rather, to situate the wandering eye within a more expansive structure of smoke and mirrors - the arcades themselves Benjamin demonstrates that the shop-front resembles not only a window of opportunity for the flâneur, but an optic through which to glimpse the process of his own refashioning as an object of desire.

If the consequences of window-licking remain to be seen, in some sense, for Ponto and his board of directors, Benjamin is swift to read the signs, and to recognize the passionate spectator as a source of congestion, rather than its witness or casualty. ${ }^{47}$ The flâneur had always posed a threat to the logic and logistics of traffic, of course, as anybody would who winds his way through urban life at the speed of a tortoise; and it is for this reason exactly that the flâneur, popularly conceived, is welldisposed to consider the arcades a home from home, a venue perfectly suited to one who longs to inch, tortoise-like, through the hubbub of 'life in all its variety'. ${ }^{48}$ Yet

The Other Jewish Question: Identifying the Jew and Making Sense of Modernity (New York: Fordham University Press, 2011), pp. 197-99.

${ }^{46}$ Baudelaire reflects on the 'fertile' possibilities of window-shopping in 'Les Fenêtres’, in Euvres complétes, vol. 1, ed. Claude Pichois (Paris: Gallimard, 1975), p. 339. Baudelaire's twinkling analogy, 'a kaleidoscope gifted with consciousness', comes from his essay 'Le Peintre de la vie moderne' (1863), in Curiosités esthétiques, L'Art romantique et autres Euvres critiques, ed. Henri Lemaitre (Paris: Bordas, 1990), p. 464.

${ }^{47}$ It seems reasonable to assume that Benjamin has the French idiom for windowshopping in mind: 'faire du lèche-vitrines'.

${ }^{48}$ Benjamin, 'The Paris of the Second Empire in Baudelaire' (1938), trans. Harry Zohn, in The Writer of Modern Life: Essays on Charles Baudelaire, ed. Michael W. Jennings (Cambridge, MA: Belknap Press of Harvard University Press), pp. 68-69. In various instantiations of his work on the arcades, Benjamin records a myth that continues to surface in critical accounts of flânerie - that is, the craze in 1839-40 for 
domestic arrangements have a nasty way of stiffening, and the problem, to Benjamin's mind, is that the flâneur has made himself almost too at home in the arcades, has become, as we like to say, part of the furniture. After so much dawdling, the flâneur looks to have become a product of his own making - 'He is merchandise' [Er ist Ware] - and in this sense must be considered a burden or stay upon passing trade, a distraction from the stricter rules of traffic-sense. Thus he comes to resemble an unlikely saboteur [Der Flaneur sabotiert], and just one more instance of the way trafficking is prone to miscarry, displacing or eliding the subject-object relations that lie at the heart of Verkehr. To while away an hour in the arcades is to absorb the precise meaning of extravagance, yet to do so might also be to forget yourself in ways that leave a body open to speculation and the pull of market forces.

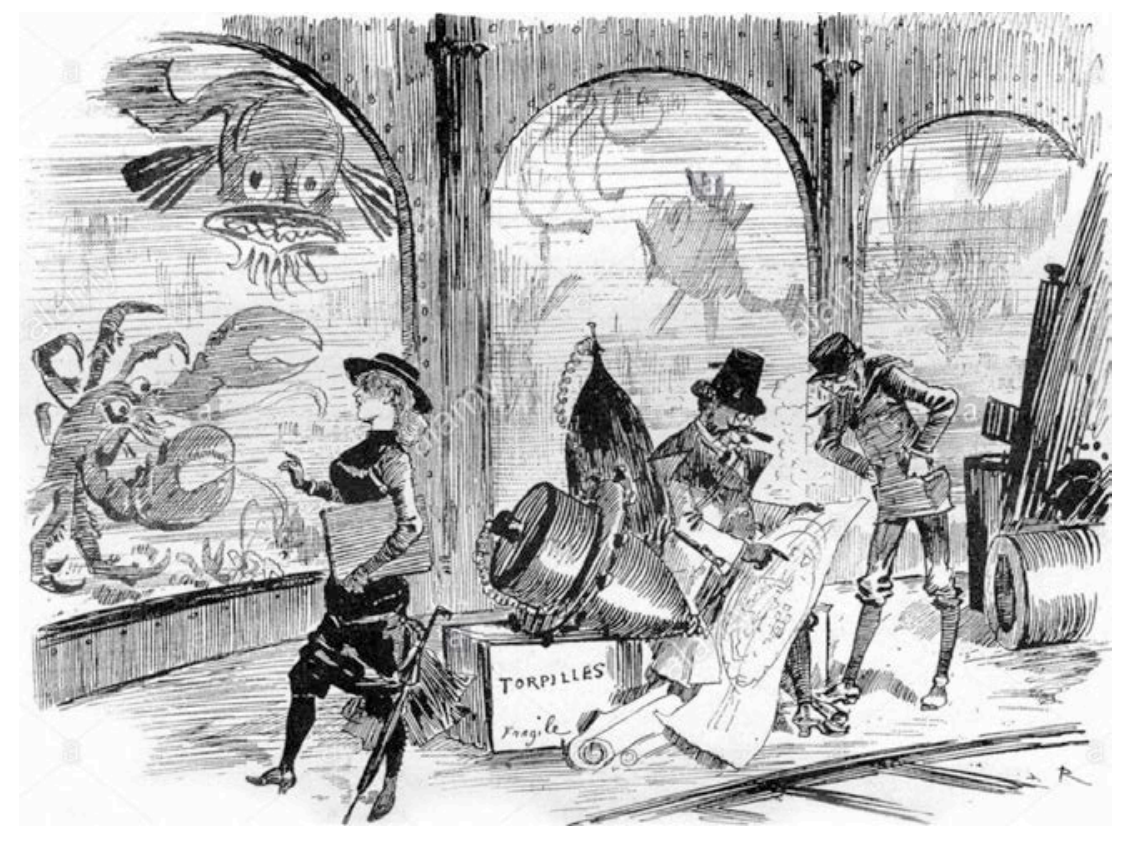

Figure 2.

Transatlantic flânerie: Hélène inspects Ponto's 'aquarium supérieurement monté' (illustration by Robida)

walking tortoises around the streets of Paris. See 'The Paris of the Second Empire in Baudelaire', p. 84. 
Though circuitous in its way, this detour through the Arcades was occasioned by my trying to elucidate Robida's no less convoluted response to a bygone modernism. For him, as for Benjamin, the creation of infrastructure raises unsettling questions about security and governance, the seductions of a fluid political economy, and the kinds of behaviour that cannot easily be policed in a world whose frontiers have begun to dissolve. The challenge of ensuring safe passage through his pneumatic network strikes Monsieur Ponto as an opportunity in disguise, a chance to nurture a captive audience, and so to do what Benjamin fears by turning traffic into trade. The idea of populating Ponto's arcades with 'les savants' [scholars] does something to appease the more old-school of the board's directors, but really, it's the prospect of playing roulette among the fishes that seems to swing the vote, and to convince the assembled members that pneumatic excursions will appeal also to 'les gens du monde' (p. 260) [society people]. Talk of American imperialism dwindles in the face of Ponto's bid for renewed investment, though he agrees, for the sake of appearances, to incorporate a defence system that would allow them to block or flood the tunnel in times of crisis. Fifteen pages later - because this is a world where building projects materialize ahead of schedule, if not always under budget - Hélène is packed off to the ocean floor for a sneak preview (fig. 2). A crab seems to claw at the aquarium casement, and a bearded fish swims into view, both of them affronted by the woman's outstretched hand, and insensible (for the moment, at least) to her companions' scheming. For while Hélène tries to put her finger on it - on the 'mystérieux' nature of a life lived at high pressure (p. 273) - Ponto and his chief engineer mull over the network's commercial potential. Perched on a crate of torpedoes that has been stowed away in case of American invasion, Ponto realizes that sniping could have a future, and that there's a pretty penny to be made from 'chasses sous-marines' [underwater hunting] (p. 275). That Parisians will pay good money to risk life and limb on the ocean floor may come as no surprise, but one wonders where Ponto's colonial ambitions will end. Such are the ways, perhaps, of tunnel vision.

\section{Pneus and Bleus}


Ponto's transatlantic experiment is not quite the end of the story, either for Robida or for the history of pneumatics. The subject of American foreign policy surfaces once more in the next chapter of Le Vingtième Siècle, where we learn that Britain has ceded control to a deputation of Mormons, and that those who 'débarquez sur le pavé de Londres' [embark on the streets of London] should keep their wits about them (p. 275). Scaremongering of this sort was not to everyone's liking in the 1880s, and among those to embrace 'l'américanisation' was Michel Verne, son of Jules, who could see the advantage of building links with English-speakers. In 1889 Verne Jr. treated readers of The Forum, a New York monthly, to a story entitled 'In the Year 2889', and this was followed by the translation of an earlier fiction, 'Un Express de l'avenir', in 1895. ${ }^{49}$ Though economical on aspects of plot and character development, 'An Express of the Future' goes further than most stories of this period, further even than Robida's, in proposing a mode of transportation that combines speed and luxury. After some initial confusion as to where he is and what he's doing, Verne's narrator learns that he is in Boston, and that an inventor, Colonel Pierce, whose exploits he's read about in an American newspaper, is on hand to enumerate the tube's finer properties, from air-conditioning to bespoke upholstery. This is evidently the way to travel between Boston and Liverpool, and the only consequences Pierce can foresee in taking the tube have to do with its reducing one to fits of giggles. Since the pressurized train can reach speeds of $1118 \mathrm{mph}$ (Verne had clearly read his Robida), it is now possible for a traveller to 'quit[...] Liverpool at noon', Pierce reasons, and to 'reach the station where we now are at thirty-four minutes past nine in the morning - that is to say, earlier than he started! Ha! Ha!' The gag is all but lost on the incredulous narrator, who wonders whether he's fallen in with a 'madman', but readers of the Strand would doubtless have got the joke: after so many years of sailing between the Old World and the New, travelling from Liverpool to Boston now means travelling back in time.

Verne's tale of transatlantic deviltry, sad to say, has not aged well. Pierce's 'fabulous theories' are unlikely to fly with most twenty-first-century readers, who are

\footnotetext{
49 'In the Year 2889' [À l'année 2889] was published under Michel’s father's name in The Forum 6.6. (February 1889), 662-77; 'Un Express de l'avenir', which had appeared in Le Figaro in September 1888, was presented as 'An Express of the Future' in the Strand Magazine (Jul-Dec 1895), 638-40, again (mistakenly) under Verne Sr.'s name.
} 
used to zipping across time-zones, and for whom a 'dull rumble' underground has become a daily soundtrack. By the same token, it's difficult not to feel let down by Verne's brusque conclusion: a narrator waking up to find that it was all a dream might have stunned readers in 1888 or 1895; now, of course, it sounds like the oldest trick in the book. One thing does ring true, however, and that's the importance Verne attributes in 'An Express of the Future' to waking thoughts. Tubes, traffic, currents of air - the narrator realizes that he's seen it all before, and that the stuff of dreams, of this dream specifically, bears a material resemblance to the infrastructure of central Paris, where 'despatches are conveyed pneumatically'. The narrator is not unusual in seeking to naturalize the oddities of his vision by clutching at known coordinates, yet it's striking that pneumatic travel no longer amounts to a paradigm shift or 'litanie', as it had for Verne Sr. in the progressive 1860s, but rather a kind of recreation one might undertake 'complaisantly', as though it were nothing more than a plaything, or a trivial corollary of existing network capability. ${ }^{50}$ With a teasing nod to Robida's torpedo-strewn tunnel along the seabed, Verne Jr. sticks with the artillery theme, though softens the blow somewhat by imagining a 'pea-shooter of interminable length'.

Pneumatics had come a long way by the 1890s, but it's safe to say that Verne's toying fable would have done little to persuade readers on either side of the Atlantic that pneumatic transport was yet fit for widespread use. Parisian readers, at least, might have smirked to hear Verne's inventor extolling the sanitized virtues of the technology, for while the word 'pneumatique' had gained some traction in the years following the Second Empire's dissolution, few witnesses to the volatile Third Republic could in all conscience have associated the term with a fresh start. Winding its way below the streets of Paris, la Poste Pneumatique was made fully available to the public in May 1879 - a sign of real progress, no doubt, on the part of the recently amalgamated Postes et Télégraphes, but one that bore a definite whiff of the Haussmann regime, whose plans to renovate the capital's vast network of sewers were now resurrected with a view to enshrining the new communication system. In 1881, a proposal to develop the network was granted, thereby supplanting the original 1kilometer loop with a web of single and double tubes that would extend throughout the arrondissements, into the farther reaches of the Seine-et-Oise département. 'The

${ }^{50}$ Paris au $X X^{e}$ siècle, p. 36. 
pipes of the pneumatic post of Paris have found a comfortable and safe asylum in the vaults of the sewers', one commentator observed, intrigued by the rising fortunes of Haussmann's legacy: 'Paris is the only city in the world with this magnificent subterranean construction, which meant, initially, receiving the stream of impure greywater, the litter of the ateliers, and the sludge from the street, but eventually giving shelter to the new devices science has created for the greater welfare of the inhabitants of the cities'. ${ }^{51}$ The benefits of sending a 'pneu' were readily apparent to those who felt the electric telegraph had begun to cramp their style. Unlike a standard telegram, whose cost was calculated according to the number of words expended, a pneu purchased at the fixed-rate provided correspondents with the opportunity to be flowery in word as well as thought, tempered only by the physical parameters of the thin letter-cards supplied by the Postes et Télégraphes. Not until 1898 were private writing materials admitted into general circulation, yet a good many customers remained faithful to the service's official stationery, and particularly to the range of light blue letter-cards that were to accrue a special reputation in the years leading up to the First World War. ${ }^{52}$ The reign of the infamous petit bleu had begun.

And that, for the time being, is where this history of pneumatics has to end. Novelists would continue in the wake of Robida and the Vernes to imagine the utopian possibilities of transatlantic exchange, though rarely with the same warmth for conspiracy and somatic revelation that characterise the tribulations of Dufrénoy and Boutardin, Colobry and Ponto. ${ }^{53}$ Where, for these fictional creations, the dubious charm of travelling at high pressure arises in large measure from their brush with a prototype - with a technology feeling its way towards definition and definitive application - later operators such as Orwell's Winston Smith seem peculiarly unmoved by 'the current of warm air' that signals a pneumatic event, in part, of

\footnotetext{
${ }^{51}$ Louis Figuier, Les Merveilles De La Science, Ou Description Populaire Des Inventions Modernes, 5-6 (Paris: Furne, Jouvet et Cie, 1867-91), p. 511 (translation by Molly Wright Steenson). For a brief overview of the Parisian pneumatic network, see Steenson, 'Interfacing with the Subterranean', Cabinet: A Quarterly of Art and Culture 41 (2011), 82-86.

${ }^{52}$ For changes in design and rates of postage, see J. D. Hayhurst, The Pneumatic Post of Paris, ed. C. S. Holder (n.p.: France and Colonies Philatelic Society of Great Britain, 1974), available online: http://www.cix.co.uk/ mhayhurst/jdhayhurst/pneumatic/book1.html (accessed 1 August 2016).

53 See, for instance, Bernhard Kellermann’s Der Tunnel (1913), and Harry Harrison's Tunnels Through the Deeps (1972).
} 
course, because Smith's involvement in such an event has taken a turn for the 'automatic'. ${ }^{54}$ With its introduction to high-rise establishments in the early decades of the twentieth century, communication of this kind was to lose something of its culvert, subterranean mystery, such that one must search long and hard in the fiction of these years to detect its vestigial aura, in the flutter of a rushed petition, or in the associations of a place-name - Balbec - boosted vicariously by 'une force pneumatique'. ${ }^{55}$ In writing 'towards' a history of pneumatics, I have begun here to recuperate a sense of writing under pressure at a time when the process of doing so was still wont to feel like a plot development. The stuff of air-borne traffic once required prolonged attention, and so it should again, both for the things it has to tell us about the cracks and openings of media archaeology, and for the ways it might prompt us to rearrange certain kinds of fact and fiction, so as to account for the possibility that invention, properly conceived, is a literary pursuit as much as it is a scientific one. The history of pneumatic transmission is littered with examples of ingenuity and misapplication, quick thinking and idiocy, with the result that recent attempts to render the technology legible have inclined to a sort of absurdist longing for a world where anything goes. Another study might resume with the fantasies of Terry Gilliam or the pranks of Thomas Pynchon. But those stories can wait. The tubes, oddly enough, aren’t going anywhere.

\footnotetext{
${ }^{54}$ Nineteen Eighty-Four (London: Penguin, 2000), p. 44.

${ }^{55}$ See Lambert Strether's pressurized encounter with a petit bleu in James's The Ambassadors, ed. Nicola Bradbury (Cambridge: Cambridge University Press, 2015), pp. 359-61; Marcel Proust, À l'ombre des jeunes filles en fleurs, II (Paris: Gallimard, 1988), p. 21.
} 


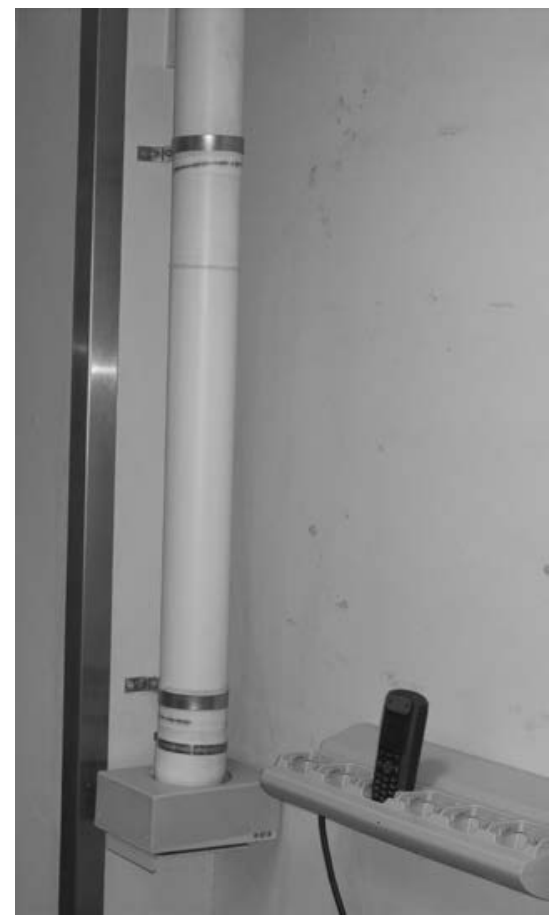

Figure 3. Supermarket media in the twenty-first century - a pneumatic tube and a cordless telephone.

(Author's photograph) 